This manuscript is contextually identical with the following published paper: Ágnes Bolgovics, Gábor Várbíró, Éva Ács, Zsuzsa Trábert, Keve Tihamér Kiss, Virág Pozderka, Judit Görgényi, Pál Boda, Balázs-A Lukács, Zsolt Nagy-László, András Abonyi, Gábor Borics, Phytoplankton of rhithral rivers: Its origin, diversity and possible use for quality-assessment, In Ecological Indicators, Volume 81, 2017, Pages 587-596, ISSN 1470-160X, https://doi.org/10.1016/j.ecolind.2017.04.052.

The original published PDF available in this website:

http://www.sciencedirect.com/science/article/pii/S1470160X17302406)

\title{
ECOIND3679
}

DOI: 10.1016/j.ecolind.2017.04.052

\section{Phytoplankton of rhithral rivers: its origin, diversity and possible use for quality- assessment}

Ágnes Bolgovics ${ }^{1}$, Gábor Várbíró ${ }^{2}$, Éva Ács ${ }^{3}$, Zsuzsa Trábert ${ }^{3}$, Keve Tihamér Kiss ${ }^{3}$, Virág Pozderka ${ }^{1}$,

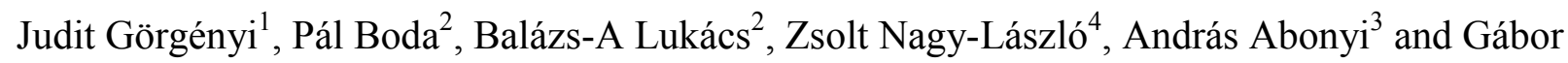
Borics $^{2}$

${ }^{1}$ University of Eötvös Loránd, H-1117 Budapest, Pázmány Péter Str. 1/A, Hungary

${ }^{2}$ MTA Centre for Ecological Research, Danube Research Institute, Department of Tisza Research, H-4026 Debrecen, Bem square 18/c., Hungary

${ }^{3}$ MTA Centre for Ecological Research, Danube Research Institute, H-1113 Budapest, Karolina Str. 29, Hungary

${ }^{4}$ University of Pannonia, Department of Limnology, H-8200 Veszprém, Egyetem Str. 10, Hungary

Corresponding author: bolgovics.agnes@okologia.mta.hu

\section{Abstract}

While phytoplankton studies on large potamal rivers have increased in number in recent years, upper river sections have received considerably less attention. However, in order to better understand processes that govern the development of dominance of euplanktonic elements in the lower river sections, detailed studies of the upstream areas are necessary. We studied the composition, diversity and recruitment of the planktonic algal communities in the River Sajó and in its main tributary River Hernád, two characteristic rhithral river systems in Central Europe. Results revealed that diatoms are dominant elements of the phytoplankton in the upper river segments both in terms of taxa richness, and relative abundance. We found that composition of the phytoplankton showed the closest resemblance to that of benthic communities of soft substrates, highlighting the key role of riverbed characteristics in river phytoplankton recruitment. The occurrence of euplanktonic elements was not restricted to human 
impacted river segments, these taxa also occurred in pristine headwaters. Accordingly, planktonic algae potentially colonise small headwater streams naturally, although their dominance is expected to occur only at downstream reaches following impounded river segments. Diatom metrics used in ecological state assessment were calculated for the rithroplankton. These metrics fell in the range of values calculated for diatom flora on the hard substrates. However, the potential use of rithroplankton for quality assessment might be limited, because the high variability of index values at site level would result in misclassification of the ecological status.

Keywords: diatom metrics; ecological status; rhithroplankton; rhithral rivers

\section{Introduction}

Phytoplankton is the main primary producer in the pelagic zone of marine and lake ecosystems. Being the basis of the food chain, this group received considerable scientific interest since the early ages of oceanographic and limnological research. Although there is wealth of scientific information about phytoplankton assemblages of lakes, our knowledge about riverine phytoplankton is still limited (Szemes, 1967; Uherkovich, 1969; Schmidt, 1994; Kiss, 1995; Dokulil, 2013, 2014; Bolgovics et al., 2015). Partly because the basis of the food chain is allochthonous material, and partly because respiration is greater than in-stream primary productivity, rivers are basically considered as heterotrophic systems (Welker and Walz, 1999), where autotrophic production is only of secondary importance. However numerous studies demonstrated that the existence of ecosystems in the middle section of large rivers are not based exclusively on the inefficient processing of organic matter, as stated in the River Continuum Concept (RCC) (Vannote et al., 1980). Several studies demonstrated that large rivers enriched in nutrients provide suitable conditions for phytoplankton development (Kiss, 1996; Kiss and Genkal, 1996; Reynolds and Descy, 1996; Wehr and Descy, 1998; Vörös et al., 2000). Phytoplankton assemblages of these rivers show similar characteristics to those typically observed in shallow turbid lakes (Reynolds et al., 1994). In both systems dominant species have fast growth rate and tolerance to highly turbid, light limited environments (Reynolds, 1988; Reynolds et al., 1994; Kiss, 1995). In temperate rivers Centric diatoms, Chlorococcalean green algae and small cryptophyceans are the most frequently occurring elements of the phytoplankton (Rojo et al., 1994; Schmidt et al. 1994; Kiss and Schmidt, 1998; Kiss et al., 2006). However, there are considerable differences between the natural habitat templates provided by the upper or lower river segments. In the lower potamal river sections, increased water depth and reduced light have been considered as the most limiting constraints of algal growth. While in the upstream river segments mostly the short water residence time (Borics et al., 2007), the high dilution rate (Billen et al., 1994) and the filter-feeding stream invertebrates limit algal growth (Ward and Stanford, 1983, Köhler et al., 2002). At these upstream sections, the low-biomass phytoplankton consists primarily of tychoplanktonic elements 
(Blum, 1954, 1957; Uherkovich, 1966; Rojo et al., 1994), i.e. species that entrained in the plankton after detached from the substrates (Swanson and Bachmann, 1976).

The rivers are not isolated ribbons of water. They are elemental parts of the landscape connecting with other water bodies of the river valley. The various kinds of stagnant waters of river catchments including small pools and ponds, connecting marshlands, shallows of the rivers and artificial impoundments continuously enrich the phytoplankton with euplanktonic elements (Stoyneva, 1994; Borics et al., 2007). Therefore, riverine phytoplankton appears to be an eclectic mixture of the planktic and benthic algae of different origin (Uherkovich, 1970; Pajak and Kiss, 1990; Kiss and Ács, 2009; Borics et al., 2014).

As it was mentioned above, habitat characteristics of the upper, rhithral river segments show considerable differences to that of the lower river stretches. Rhithral river systems possess a large variety of well illuminated benthic habitats, where on the solid-water interface diverse benthic algal assemblages may develop. Since dispersal of algae is aided by air or animal vectors (Padisák et al., 2016), theoretically these habitats can be colonised naturally by euplanktonic taxa, which can survive in benthic habitats both in lakes (Borics et al., 2003) and in rivers (Istvánovics and Honti, 2011). Due to physical disturbance (i.e. increase in discharge), these taxa together with benthic algae can split off from the substrates and become the natural elements of the phytoplankton. However, this possibility has not been thoroughly investigated.

At a whole river scale, the sooner the dominance of euplanktonic elements occurs in the phytoplankton, the sooner opens the opportunity for the development of large biomass assemblages, leading also to decrease in water quality, which adversely affect water uses (Wehr and Descy, 1998). Therefore, the question of in which segments of the rivers euplanktonic species occur first and dominate in the riverine plankton has a crucial importance.

The tychoplanktonic/euplanktonic transition in the upper river segments has been demonstrated in several studies (Abonyi et al., 2014; Stankovic et al 2012), and has been used in the phytoplanktonbased river quality assessment (Borics et al., 2007; Abonyi et al., 2012). However, while the functional approach successfully represents water quality changes at whole river scale, it is much less sensitive in the uppermost river sections. Therefore, application of the metrics developed for benthic diatoms seems potentially promising to characterize the phytoplankton and the fine scale differences in the ecological state of the uppermost river segments.

The aim of this study was to investigate the phytoplankton and benthic algal communities in a relatively unaltered rhithral river system, focusing on the questions of how euplanktonic elements entrain into the riverine phytoplankton; (ii) how diversity of the phytoplankton changes at both site and catchment levels; and (iii) how riverine phytoplankton can be used in water quality assessment. In order to avoid terminological misunderstandings, we use the term rhithroplankton (Bolgovics et al., 2015) for the plankton of rhithral rivers in this study.

We hypothesize that 
(i) various benthic habitats contribute differently to the phytoplankton of rhithral rivers;

(ii) planktonic diatoms occur even in the benthos in the uppermost river sections;

(iii) water quality metrics calculated for the rhithroplankton indicate similar ecological status than those computed for benthic diatom composition.

\section{Material and methods}

\subsection{Study area}

We studied the benthic and rhithroplanktonic algal assemblages of the River Sajó basin (SlovakiaHungary), a characteristic rhithral river system in Central Europe. The River Sajó system belongs to the River Tisza catchment and consists of two rivers (River Sajó and River Hernád) with almost equal sizes and with similar hydromorphological characteristics (Table 1), and including streams of $1^{\text {st }}$ to $6^{\text {th }}$ river orders. The Slovakian mountainous and the Hungarian lowland sections contain large variety of riverine habitats.

\subsection{Sampling}

Altogether 42 sampling sites were included in our survey, covering the two river catchments. Besides the main river channels, several small tributaries were also sampled. Because of the low abundance of algae in the rhithroplankton, twenty liters of water taken from the thalweg was filtered using a $10 \mu \mathrm{m}$ plankton net in every sampling site. The filtered material was concentrated to $50 \mathrm{~cm}^{3}$, fixed with formaldehyde (4\% final concentration) and stored in plastic containers.

In order to study the role of substrate types in shaping riverine algae compositions, various substrates characteristic for each sample site were sampled. In the upper river segments four substrates (stones from the thalweg, stones from pools, woods, plants (i.e. mosses or filamentous algae) were sampled. In sites of the lower river segments psammon samples were also collected. Benthic diatoms were collected using the EN 13946:2014 standard. In each site at least five replicates were sampled from each substrate and then mixed together. The material was washed into plastic container and fixed with formaldehyde. Altogether 128 benthic and 42 plankton samples were collected (Table 2).

\subsection{Sample processing}

Environmental variables ( $\mathrm{pH}$, conductivity, dissolved oxygen and water temperature) were measured on the field using a multiparametric portable meter (Hach-Lange HQ40D).

Phytoplankton samples were analyzed using the inverted microscope technique (Utermöhl, 1958; Lund et al., 1958). The functional characteristics of rhithroplankton was assessed by using the functional 
groups concept sensu Reynolds et al. (2002) and Borics et al. (2007), recently reviewed by Padisák et al. (2009).

For diatom identification, $1 \mathrm{~cm}^{3}$ of the phytoplankton samples and materials collected from benthic substrates were digested with hydrogen peroxide, rinsed with distilled water, and then mounted on slides using Cargille Meltmount medium (refractive index=1.7). Diatoms were identified and counted using Zeiss Axioimager A2 upright microscope, at a magnification of $1000 \times$ applying oil immersion and differential interference contrast (DIC). Altogether 400 valves were counted in each sample.

\subsection{Statistical analyses}

Composition of the microflora was expressed as relative abundance of functional groups and evaluated in the various stream orders, determined by visual inspection of appropriate maps proposed by Stahler (1952).

As diversity metrics based on abundance data are frequently affected by short-term physical disturbances (Borics et al., 2013), in this study, species richness was used as a measure of diversity both at site- and catchment-scale levels. Chao's sample based extrapolation curves (Chao et al., 2014) were used to compare the contribution of the various substrate types to the catchment-scale diversity of the River Sajó. Because of the hydrological and morphological differences of the sampling sites, not all substrate types have been sampled, thus the numbers of substrates were not equal. Accordingly, during the catchment-scale richness estimation, besides the plankton samples, only those substrates were considered which number at catchment scale was larger than 15 . These were the followings: stone from the thalweg, stone from pools, wood, psammon and plant.

In order to determine the most important substrates in the development of rhithroplanktonic algal assemblages, Jaccard similarity coefficients (incidence data) and Euclidean distances (abundance data) were calculated between the planktonic and the benthic communities from different substrate types. One-way analysis of variance (ANOVA) and Tukey's pair-wise test were used to determine significant differences among values of Jaccard similarity coefficients and Euclidean distances in the different substrates.

To study the benthic-planktonic shift in the phytoplankton composition, relative abundance of euplanktonic algae was studied at each sampling site. In order to obtain higher resolution of size differences among the streams, we considered the distance of each sampling sites from the source. Distances were measured on Google Earth images of the catchment. Percentage of the planktonic algae was plotted against this distance.

Several diatom-based metrics have been developed to assess the ecological state of rivers in recent decades. In this study the three elements of multimetric index (IPSITI) applied in ecological status assessment of Hungarian running waters (Várbíró et al. 2012), the IPS (Coste in Cemagref, 1982), the SID and the TID index (Rott et al., 1997, 1999) were used to determine river quality based on 
rithroplankton and the algal composition of various substrates. All the three indices base on the Zelinka and Marvan formula:

$$
\operatorname{Index}(I P S, S I D, T I D)=\frac{\sum_{i=1}^{n} a_{i} s_{i} v_{i}}{\sum_{i=1}^{n} a_{i} v_{i}}
$$

where $\mathrm{a}_{\mathrm{i}}$ : abundance or proportion of valves of species $i$ in the sample, $s_{i}$ : pollution sensitivity (optimum) of species $i$ and $v_{i}=$ indicator value (tolerance) of species $i$.

To assess the relationship between the various metrics (IPS, SID and TID) calculated for the benthic and rhithroplankton samples, the Pearson correlation coefficient was computed (Table 3). Statistical analyses were performed using the STATISTICA package (version 6; StatSoft Inc., Tulsa, OK, USA).

\section{Results}

\subsection{Composition of the rhithroplankton}

Results on algal composition of samples showed that benthic diatoms had overwhelming dominance in the rhithroplankton both in terms of abundance (Fig. 1a) and taxonomical richness (Fig. 1b.). The nondiatom components of the plankton constituted only a small proportion of the phytoplankton, however, their ratio increased steadily with increasing stream order. This feature was observed both for the abundance and richness data (Fig. 2a and Fig. 2b). Planktonic diatoms (C and D functional groups), small single-celled and colonial chlorococcalean green algae (belonging to the $\mathrm{X} 1, \mathrm{~J}, \mathrm{~F}$ functional groups) were the most frequent elements occurring in the plankton (Fig. 2b).

\subsection{Diatom diversity of the rhithroplankton and of the substrates at site-and catchment-scales}

Altogether 411 diatom species and lower taxa in 66 genera were identified in our samples. The observed species richness of rhithroplankton and that of the substrates showed considerable differences (Table 2). Plankton samples appeared to be the richest in diatom taxa, while substrates stone from the pool were the most species-poor habitats. Besides some euplanktonic taxa such as Cyclotella distinguenda, Thalassiosira lacustris, Stephanodiscus cf. medius, S. minutulus, several large sized benthic taxa, such as Cymbella, Encyonema, Epithemia, Fragilaria, Gomphonema, Gyrosigma, Navicula spp. were found exclusively in the plankton samples.

The position of the sample-based rarefaction and extrapolation curves indicated that the species richness of plankton samples exceeded that of the benthic substrates (Fig. 3). Species accumulation curves of three substrates (plant, wood, stone pool) showed asymptotes at about 200 and 250 species number. Neither the species accumulation curves of the plankton samples nor the curves of the stone from the thalweg had plateau-like shapes. Both curves showed steep increase even at $60-80$ sample number range. These two lines are predicted to meet at sample number $\approx 80$.

\subsection{Species recruitment into the phytoplankton}


To answer the question of which benthic diatoms are recruited into the rhithroplankton, composition of the plankton samples and that of the various substrates were compared. The ANOVA and pair-wise comparisons showed significant differences among the algal composition of different substrate types and that of the plankton samples both based on Euclidean distances $\left(\mathrm{F}_{[5,165]}=3.5514, \mathrm{p}=0.00447\right)$ (Fig. 4a) and on Jaccard coefficients $\left(\mathrm{F}_{[4,117]}=5.8934, \mathrm{p}=0.00023\right)$ (Fig. 4b). Algal composition of plankton samples showed the greatest resemblance to the microflora of plant and psammon substrates. In terms of Euclidean distances, the plankton samples were the closest to the plant, psammon and to the stone pool samples.

\subsection{Appearance of euplanktonic forms}

In order to localise those river sections where the dominance of euplanktonic elements is expected to occur, a clear differentiation between euplanktonic and benthic taxa is needed. However, this ecological distinction needs detailed taxonomical resolution. For example, filamentous blue-greens and Protococcus-like chlorococcaleans frequently occurred in the net plankton samples, but because of the limitations of the inverted microscope technique identification of these taxa at species level is really challenging, and thus, the origin of these algae (euplanktonic or benthic) could not be identified in every case. Therefore, we focused exclusively on diatoms, where species level identifications and consequently the appropriate ecological (benthic/planktonic) distinctions could be identified. Although in general the relative abundance of planktonic diatoms (mostly centric diatoms) showed a consistent increase with the size of the streams (Fig. 5a), these algae were occasionally lacking in samples taken from the lower river reaches. As planktonic species can settle down and captured in the boundary layers of the substrates, their relative abundance in the benthos has been also investigated (Fig. 5b). The observed pattern was rather similar to that found for the plankton samples. Abundance of planktonic forms showed a considerable, continuous increase in case of sampling sites, which distances from the source were larger than $10 \mathrm{~km}$.

\subsection{River quality assessment}

Using the diatom composition of five different substrate types and that of the rhithroplankton, three water quality indices were calculated (Fig. 6a-c). Values of the IPS and SID metrics calculated for wood, stone from pool, stone from the thalweg and plant samples were found to be in similar range, while the metrics calculated for the psammon samples were significantly lower $(p<0.05)$. In case of the trophic index (TID), considerably different distribution of the values was observed. As it was found for the IPS and SID metrics, the psammon samples had the smallest, while the wood and stone samples the highest index values. Values of the rhithroplankton and the plant samples fell in the middle of the TID index range. The Pearson correlation tests indicated that indices' values of rithroplankton were the most similar to those calculated for the plant substrates (Table 3).

We also investigated how the assessment results based on the rhithroplankton and the substrates stone from thalweg and plants related to each other depending on the position of the sampling sites in the 
catchment. Differences of these values (Difference ${ }_{\text {stone, plankton }}=\mathrm{IPS}_{\text {stone }}-\mathrm{IPS}_{\text {plankton }}$ and Difference $\mathrm{plant}_{\text {, }}$ plankton $=$ IPS $_{\text {plant }}-$ IPS $\left._{\text {plankton}}\right)$ were plotted against the spatial distances of sampling points from the source (Fig. 11-12). When the stone and plankton samples were compared, the rivers (and sites) could be separated into two groups. In case of rivers stretches shorter than $<10 \mathrm{~km}$ in length, the IPS $_{\text {stone }}$ metric displayed higher values than those calculated for the plankton samples (Fig. 7a). In larger

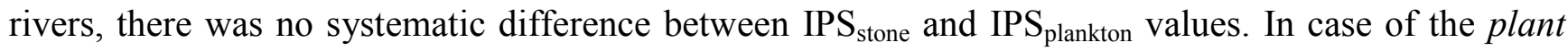
substrates whose indices' values showed the closest resemblance to the plankton samples (Fig. 7b) the rivers could be divided into three sections. In small rivers (distance from the source is $<10 \mathrm{~km}$ ) the plant samples indicated better conditions; while in larger rivers (distance from source $>40 \mathrm{~km}$ ) an opposite tendency could be observed. In middle sized rivers (in the range of 10 to $40 \mathrm{~km}$ river length) such a tendency was not observed.

\section{Discussion}

\subsection{Composition of the rhithroplankton}

264 Since phytoplankton of rhithral rivers is dominated by benthic algae detached from the substrates (Blum, 1954; Uherkovich, 1969), benthic assemblages basically determine the algal composition of divisions, only cyanobacteria, chlorophytes and diatoms occur frequently in river phytobenthos (Hendricks and Luttenton, 2007; Schaumburg et al., 2004). Our results, however, indicated that these major algal groups do not contribute equally to the phytoplankton. In our case, diatoms gave the highest contribution to the plankton, both in terms of taxonomical richness and abundance, implying that this group adapted most successfully to the strong and selective riverine environment. Besides the benthic life forms, euplanktonic algae also appeared in the rhithroplankton. The occurring taxa belonged to those functional groups $(\mathrm{C}, \mathrm{D}, \mathrm{J}, \mathrm{F}, \mathrm{X} 1$; mostly planktonic diatoms and various chlorococcalean green algae) which dominance has been repeatedly identified in middle to downstream river sections of lowland rivers (Schmidt, 1994; Reynolds and Descy, 1996; Bahnwart et al., 1999; Friedrich and Pohlmann, 2009; Tavernini et al., 2011; Várbíró et al., 2007).

\subsection{Benthic diatom diversity}

The overall diatom taxonomic richness highlighted in our study in River Sajó catchment corresponds well with those reported from other temperate river catchments e.g. Idaho rivers (350 species, 46 genera, Fore and Grafe 2002); Rhone (931 species, Rimet and Bouchez 2012); small to large rivers in Hungary (496 species, Van Dam et al. 2007). The number of taxa identified in our study is relatively high considering the relatively small catchment size of the River Sajó $\left(12,708 \mathrm{~km}^{2}\right)$. Distinct gradients in depth and current velocity, alternation of riffles and pools, differences in sediment types create high mosaicity in benthic habitats and in the corresponding algal communities (Pringle et al., 1988). In our 
study, the high number of observed taxa can be partly explained by the large sampling effort. However, it is also important to note that in our study not only the benthic flora, but diatoms of plankton samples were also considered. One potential limitation of the applied phytoplankton sampling method (net sampling) is that large sized taxa can be over-, while the smaller ones underrepresented in the net samples. On the one hand, it means that this approach might result in some bias in the relative abundance of the taxa. On the other hand, our results revealed that this technique increased the possibility of finding rare and large sized taxa, which were not present in samples of benthic substrates.

\subsection{Species recruitment into the rhithroplankton}

We hypothesised that the contribution of various benthic habitats to the composition of the rhithroplankton is different, which was supported by the results. The algal composition of psammon, stone from pool and plant substrates showed the closest resemblance to the rhithroplankton. The common feature of these substrates is that they can be found preferably in lentic parts of streams. Algae adapted to lentic habitats may be more easily detached from the substrates as a consequence of disturbance (flood) events, compared to those species that live on stone surfaces in the thalweg and are continuously exposed to strong currents. Our findings highlight that similarly to large rivers, where river morphology (notedly river shallows) plays a key role in determining recruitment processes of phytoplankton (Stoyneva, 1994), in small upstream rhithral systems, river bed morphology also plays a crucial role in shaping rhithroplankton composition.

\subsection{Appearance of euplanktonic forms}

The increase of euplanktonic forms with increasing stream size (distance from the source), as we have demonstrated in this study, is in well accordance with the River Continuum Concept (Vannote et al., 1980), and with several field observations (Uherkovich, 1966, 1970; Hynes, 1970; Pajak and Kiss, 1990; Várbíró et al., 2007; Kiss and Ács, 2009). In some cases, however, dominance of euplanktonic forms was observed even in small streams of $1^{\text {st }}$ and $2^{\text {nd }}$ orders. While detailed investigation of the map in several cases revealed the presence of river embankments or off-river reservoirs, in some cases, the same euplanktonic taxa occurred in benthic samples from near source sampling stations $(<1 \mathrm{~km}$ distance from the source), where reservoirs or connecting lakes could not be detected. Former studies investigating the phytoplankton communities near the headwater of River Danube reported similar results (Kiss et al,. 2003). A species rich phytoplankton community was found five kilometers from the source of Breg at Furtwangen (The stream Breg is one of the "source tributary" of River Danube, the altitude is $1000 \mathrm{~m}$ at Furtwangen). Below the source several small pools (some natural bog-like pool and artificial pools for cattle) can be found. Small marshy pools with an area of few $\mathrm{m}^{2}$ are characteristic parts of creeks and drains, and can potentially capture euplanktonic species and inoculate the lower sections. Contrariwise, on the upper part of the River Danube (at Nasgenstadt) already $17 \%$ of the total species number was planktonic in the phytobenthos (Ács et al., 2003). Furthermore 15-35\% 
of relative abundance of centric diatoms was found in phytobenthos of a small Hungarian stream (Rákos-stream) by Szabó et al. (2004) originated from fishponds constructed on the stream.

However, our finding may be not surprising if we consider that algae can disperse in various ways (Padisák et al., 2016). Air as an agent for dispersal is of primary importance for many algal groups including diatoms (Chrisostomou et al., 2009). Algae can survive in aerosols and can be transported by winds over long distances, and thus, can colonize remote environments. Although the dominance of euplanktonic diatoms can be expected in lakes larger than $10^{3}-10^{4} \mathrm{~m}^{2}$ (Borics et al., 2016), low abundance populations of these taxa can be present in tiny pools as small as $10^{-2} \mathrm{~m}^{2}$ (Bolgovics et al., 2016). Thus, it can be argued that the natural inoculation of rivers by euplanktonic algae already starts from the river source areas, even if its efficiency may be much lower than expected in case of reservoirs established in upstream river sections (Abonyi et al., 2012).

\subsection{River quality assessment}

While in case of large rivers, riverine phytoplankton composition can be successfully used to evaluate ecological status (Borics et al., 2007, Abonyi et al., 2012; Stankovic et al., 2012; Borics et al., 2014), in rhithral rivers, monitoring of benthic biota' (benthic algae, macroinvertebrates and fish) provides primary information on the ecological status of water bodies (Birk et al., 2012). Based on the autecology of benthic diatoms, several metrics were elaborated and proposed to use for river quality assessment (Coste in Cemagref, 1982; Rott et al., 1997, 1999). These metrics should meet two important criteria: sensitivity to stressors and robustness. The latter is closely linked to the substrate selection. Analysing the US Geological Survey National Water-Quality Assessment program, Potapova and Charles (2005) did not find significant differences between the metric values of soft and hard substrates taken from the same sampling sites. On the other hand, Kelly et al. (1998) deemed it necessary to restrict diatom sampling to a single substrate type, and they proposed the use of rocks or other hard substrates in river quality assessment. Kröpfl et al. (2006) clearly demonstrated that biofilm production, abundance of algae and IPS diatom index were influenced by the substrates in River Tisza. Our results also support this view, as values of all the applied metrics showed large and significant differences. Despite the composition of rhithroplankton was the most similar to that of the soft substrates (psammon, plants), the index values calculated for the plankton data fell in the range of the values computed for hard substrates. At first glance, it is tempting to conclude that monitoring and evaluation of rhithroplankton diatom composition provides as reliable results as generally accepted for hard substrates, but pairwise comparison of the assessment results (Fig. 7a-b) indicated considerable differences. The differences between the values calculated for rhithroplankton and for benthic substrates covered a range of 10 scores, which would result in high uncertainty in quality assessment. Benthic diatoms are used for river quality assessment in Hungary (Szilágyi et al., 2008) and type specific boundaries were set for the metrics (Várbíró et al., 2012). Since a given quality class ranges approximately 3 scores in the Hungarian running water quality system, the observed differences 
between the values calculated for the plankton and for stone surfaces occasionally would result in two class differences in the assessment results.

\section{Conclusions}

Based on our detailed study of the rhithroplankton of Sajó-Hernád river system (Central Europe) the following conclusions can be drawn:

The rhithroplankton is dominated by benthic diatoms. Since composition of the rhithroplankton shows the closest resemblance to that of the soft substrates, indirectly, river-bed characteristics (i.e. number and area of the shallows of the river channel) have a pronounced impact on phytoplankton recruitment. Since microflora of the various kinds of habitats contribute to the species pool of rhithroplankton, its diversity exceeds that of the benthic substrates both at site and catchment scale.

Dominance of euplanktonic elements in the rhithroplankton can be expected if impoundments or reservoirs are found in the catchment, but occurrence of these taxa (although in low abundance) can be observed in the unimpacted upper river segments.

Although diatom-based metrics can be calculated for the rhithroplankton, these results cannot be used as a substitute for results on benthic diatom samples, because considerable differences may occur between metric values of the plankton and that of the benthic substrates.

\section{Acknowledgements}

This work was funded by the GINOP-2.3.2-15-2016-00019, OTKA K104279, PD120775 grants and the MTA Postdoctoral Research Program (PD-019/2016).

\section{References}

Abonyi, A., Leitao, M., Lancon, A.M., Padisák, J., 2012. Phytoplankton functional groups as indicators of human impacts along the River Loire (France). Hydrobiologia 698, 233-249.

Abonyi, A., Leitão, M., Stanković, I., Borics, G., Várbíró, G. and Padisák, J., 2014. A large river (River Loire, France) survey to compare phytoplankton functional approaches: Do they display river zones in similar ways? Ecological Indicators 46, 11-22.

Ács, É., Szabó, K., Kiss, K.T., Hindák, F., 2003. Benthic algal investigations in the Danube river and some of its main tributaries from Germany to Hungary. Biologia, Bratislava, 58(4), 545-554.

Bahnwart, M., Hübener, T., Schubert, H., 1999. Downstream changes in phytoplankton composition and biomass in a lowland river-lake system (Warnow River, Germany). Hydrobiologia 391, 99111.

Billen, G., Gamier, J., Hanset, Ph., 1994. Modelling phytoplankton development in whole drainage networks: the RIVERSTRAHLER model applied to the Seine River system. Hydrobiologia 289, 119-137. 
Birk, S., Bonne, W., Borja, A., Brucet, S., Courrat, A., Poikane, S., et al., 2012. Three hundred ways to assess Europe's surface waters: an almost complete overview of biological methods to implement the Water Framework Directive. Ecological Indicators 18, 31-41.

Blum, J.L., 1954. Evidence for a diurnal pulse in stream phytoplankton. Science 119, 732-734.

Blum, J.L., 1957. An ecological study of the algae of the Saline river, Michigan. Hydrobiologia 9, 361-408.

Bolgovics, Á., Ács, É., Várbíró, G., Kiss, K.T., Lukács, B.A., Borics, G., 2015. Diatom composition of the rheoplankton in a rhithral river system. Acta Bot. Croat. 74, 303-316.

Bolgovics, Á., Ács, É., Várbíró, G., Görgényi, J., Borics, G., 2016. Species area relationship (SAR) for benthic diatoms: a study on aquatic islands. Hydrobiologia 764, 91-102.

Borics, G., Tóthmérész, B., Grigorszky, I., Padisák, J., Várbíró, G., Szabó, S., 2003. Algal assemblage types of bog-lakes in Hungary and their relation to water chemistry, hydrological conditions and habitat diversity. Hydrobiologia 502, 145-155.

Borics, G., Várbíró, G., Grigorszky, I., Krasznai, E., Szabó, S., Kiss, K.T., 2007. A new evaluation technique of potamo-plankton for the assessment of the ecological status of rivers. Archiv für Hidrobiologie, Large Rivers 17, 465-486.

Borics, G., Várbíró, G., Padisák, J., 2013. Disturbance and stress: different meanings in ecological dynamics? Hydrobiologia 711, 1-7.

Borics, G., Görgényi, J., Grigorszky, I., Nagy, Z.L., Tóthmérész, B., Várbíró, G., 2014. The role of phytoplankton diversity metrics in shallow lake and river quality assessment. Ecological Indicators, 45, 28-36.

Borics, G., Tóthmérész, B., Várbíró, G., Grigorszky, I., Czébely, A., Görgényi, J., 2016. Functional phytoplankton distribution in hypertrophic systems across water body size. Hydrobiologia 764, 81-90.

Cemagref, 1982. Etude des méthodes biologiques d'appréciation quantitative de la qualité des eaux, Rapport Q.E. Lyon - Agence de l'Eau Rhône-Méditerranée-Corse, Lyon 218 p.

Chao, A., Gotelli, N.J., Hsieh, T.C., Sander, E.L., Ma, K.H., Colwell, R.K., et. al., 2014. Rarefaction and extrapolation with Hill numbers: a framework for sampling and estimation in species diversity studies. Ecological Monographs 84, 45-67.

Chrisostomou, A., Moustaka-Gouni, M., Sgardelis, S., Lanaras, T., 2009. Air dispersed phytoplankton in a Mediterranean river-reservoir system (Aliakmon-Polyphytos, Greece). Journal of Plankton Research 31, 877-884.

Dokulil, M.T., 2013. Potamoplankton and primary productivity in the River Danube. Hydrobiologia, DOI 10.1007/s10750-013-1589-3.

Dokulil, M.T., 2015. Phytoplankton of the River Danube: composition, seasonality and long-term dynamics. In: Liska, I. (ed.), The Danube River Basin, Hdb Env Chem 39, 411-428. SpringerVerlag Berlin Heidelberg. 
European Committee for Standardization, 2003. European Standard. EN 13946. Water Quality Guidance Standard for the Routine Sampling and Pretreatment of Benthic Diatoms from Rivers. CEN, Brussels: 14 pp.

Fore, L.S., Grafe, C., 2002. Using diatoms to assess the biological condition of large rivers in Idaho (USA). Freshwater Biology 47, 2015-2037.

Friedrich, G., Pohlmann, M., 2009. Long-term plankton studies at the lower Rhine/Germany. Limnologica - Ecology and Management of Inland Waters 39, 14-39.

Hendricks, S.P., Luttenton, M.R., 2007. Benthic Algae Taxa (Exclusive of Diatoms) of the Little River Basin, Western Kentucky, 2000-2003. Journal of the Kentucky Academy of Science 68, 31-36.

Hynes, H.B.N., Hynes, H.B.N., 1970. The ecology of running waters (Vol. 555). Liverpool: Liverpool University Press.

Istvánovics, V., Honti, M., 2011. Phytoplankton growth in three rivers: The role of meroplankton and the benthic retention hypothesis. Limnol. Oceanogr. 56, 1439-1452.

Kelly, M.G., Cazaubon, A., Coring, E., Dell'Uomo, A., Ector, L., Goldsmith, B., et al., 1998. Recommendations for the routine sampling of diatoms for water quality assessments in Europe. Journal of applied Phycology 10, 215-224.

Kiss, K. T. 1994. Trophic level and eutrophication of the River Danube in Hungary. Verh.Internat.Verein.Limnol. 25, 1688-1691.

Kiss, K. T., 1996. Diurnal change of planktonic diatoms in the River Danube near Budapest (Hungary). Arch. Hydrobiol. Algol. Studies 80, 113-122.

Kiss, K. T. \& Genkal, S. I., 1996. Phytoplankton of the Danube's reservoirs in September 1995 from Germany to Hungary. In. Berczik (ed.) Limnologische Berichte Donau 1996. Band. I: 143-148. MTA Ökol. Bot. Kutint. Magyar Dunakutató Állomás, Vácrátót/Göd. ISBN 9638391200

Kiss, K. T. \& Schmidt, A., 1998. Changes of the Chlorophyta species in the phytoplankton of the Hungarian Section of the Danube river during the last decades (1961-1997). Biologia, Bratislava. $53,509-518$.

Kiss, K.T., Ács, É., Schmidt, A., Fehér, G., Hindáková, A., Hindák, F., 2003. Qualitative and quantitative changes of phytoplankton in the River Danube and its main tributaries (from Germany to Hungary). 5th Internat. Symposium, Use of algae for monitoring rivers, Poland, pp. 29.

Kiss, K.T., Ács, É., Szabó, K., Tóth, B., Kiss, Á.K., 2006. Alteration in the summer phytoplankton abundance from medium to low water level conditions in the River Danube. In: Proceeding of 36th International Conference of IAD. Austrian Committee Danube Research / IAD, Vienna. ISBN 13: 978-3-9500723-2-7. pp. 210-214.

Kiss, K. T. \& Ács, É., 2009. The algal flora of the River Bodrog. Thaiszia - J. Bot., Kosice, 19, Suppl. $1,99-124$.

Köhler, R., Tredicucci, A., Beltram, F., Beere, H.E., Linfield, E.H., Davies, A.G., et al., 2002. Terahertz semiconductor-heterostructure laser. Nature 417, 156-159. 
Kröpfl, K., Vladár, P., Szabó, K., Ács, É., Borsodi, K.A., Szikora, Sz, Caroli, S., Záray, Gy. 2006. Chemical and biological characterisation of biofilms formed on different substrata in Tisza river (Hungary). Environmental Pollution 144, 626-631.

Lund, J. W. G., Kipling, C., \& Cren, E. D. 1958. The inverted microscope method of estimating algal numbers and the statistical basis of estimations by counting. Hydrobiologia 11(2), 143-170.

Padisák, J., Crossetti, L.O., Naselli-Flores, L., 2009. Use and misuse in the application of the phytoplankton functional classification: a critical review with updates. Hydrobiologia 621, 1-19.

Padisák, J., Vasas, G., Borics, G., 2016. Phycogeography of freshwater phytoplankton: traditional knowledge and new molecular tools. Hydrobiologia 764, 3-27.

Pajak, G., Kiss, K.T. 1990. Seasonal changes of phytoplankton in the Vistula River above and below the Goczalkowice Reservoir (southern Poland). Acta Hydrobiologica 32, 101-114.

Potapova, M., Charles, D.F., 2005. Choice of substrate in algae-based water-quality assessment. Journal of the North American Benthological Society 24, 415-427.

Pringle, C.M., Naiman, R.J., Bretschko, G., Karr, J.R., Oswood, M.W., Webster, J.R., et al., 1988. Patch dynamics in lotic systems: the stream as a mosaic. Journal of the North American Benthological Society 7, 503-524.

Reynolds, C.S., 1988. The concept of ecological succession applied to seasonal periodicity of freshwater phytoplankton. Verh. Int. Ver. Limnol. 23, 683-691.

Reynolds, C. S., Descy, J. -P., Padisák, J., 1994: Are phytoplankton dynamics in rivers so different from those in shallow lakes? Hydrobiologia 289, 1-7.

Reynolds, C. S., Descy, P. P., 1996. The production, biomass and structure of phytoplankton in large rivers. Arch.Hydrobiol.Suppl.113. Large Rivers 10, 161-187.

Reynolds, C.S., Huszár, V., Kruk, C., Naselli-Flores, L., Melo, S., 2002. Towards a functional classification of the freshwater phytoplankton. Journal of Plankton Research 24, 417-428.

Rimet, F., Bouchez, A., 2012. Biomonitoring river diatoms: implications of taxonomic resolution. Ecological Indicators 15, 92-99.

Rojo, C., Alvarez, M., Cobelas, Arauzo, M., 1994. An elementary, structural analysis of river phytoplankton. Hydrobiologia 289, 43-55.

Rott, E., Hofmann, G., Pall, K., Pfister, P., Pipp, E., 1997. Indikationslisten für Aufwuchsalgen. Teil 1: Saprobielle IndikationBundesministerium für Land- und Forstwirtschaft, Wien.

Rott, E., Binder, N., Van Dam, H., Ortler, K., Pall, K., Pfister, P., et. al., 1999. Indikationslisten für Aufwuchsalgen. Teil 2: Trophieindikation und autökologische Anmerkungen. Bundesministerium für Land- und Forstwirtschaft Wien.

Schaumburg, J., Schranz, C., Foerster, J., Gutowski, A., Hofmann, G., Meilinger, P., Schneider, S., Schmedtje, U., 2004. Ecological classification of macrophytes and phytobenthos for rivers in Germany according to the Water Framework Directive. Limnologica-Ecology and Management of Inland Waters 34, 283-301. 
Schmidt, A., 1994. Main characteristics of phytoplankton of the southern Hungarian section of the River Danube. Hydrobiologia 289, 97-108.

Schmidt, A., Kiss, K.T., T.-Bartalis, É., 1994. Chlorococcal algae in the phytoplankton of the Hungarian section of the River Danube in the early nineties. Biologia, Bratislava, 49 (4), 553562.

Stanković, I., Vlahović, T., Udovič, M.G., Várbíró, G., Borics, G., 2012. Phytoplankton functional and morpho-functional approach in large floodplain rivers. Hydrobiologia 698, 217-231.

Stoyneva, M.P., 1994. Shallows of the Lowed Danube as additional sources of potamoplankton. In Phytoplankton in Turbid Environments: Rivers and Shallow Lakes. Springer Netherlands 171178.

Strahler, A.N., 1952. Hypsometric (area-altitude) analysis of erosional topology. Geological Society of America Bulletin 63, 1117-1142.

Szabó, K., Kiss, K.T., Ector, L., Kecskés, M., Ács, É. 2004. Benthic diatom flora in a small Hungarian tributary of River Danube (Rákos-stream). Arch. Hydrobiol. Suppl. 150. Algological Studies, 111, 79-94.

Szemes,G. 1967. Das Phytoplankton der Donau. In: Liepold, R. (ed.) Limnologie der Donau. Stuttgart. $\mathrm{V}, 158-179$.

Szilágyi, I.M., Madarász, J., Pokol, G., Király, P., Tárkányi, G., Saukko, S., et al., 2008. Stability and controlled composition of hexagonal WO3. Chemistry of Materials, 20, 4116-4125.

Swanson, C.D., Bachmann, R.W., 1976. A model of algal exports in some Iowa streams. Ecology $1076-1080$.

Tavernini, S., Pierobon, E., Viaroli, P., 2011. Physical factors and dissolved reactive silica affect phytoplankton community structure and dynamics in a lowland eutrophic river (Po river, Italy). Hydrobiologia 669, 213-225.

Uherkovich, G., 1966. Übersicht über das Potamophytoplankton der Tisza (Theiss) in Ungarn. Hydrobiologia 28, 252-280.

Uherkovich, G., 1969. Über die quantitativen Verhältnisse des Phytosestons (Phytoplanktons) der Donau, Drau und Theiss. Acta Bot. Acad. Sci. Hung. 15, 183-200.

Uherkovich, G., 1970. Seston Wisłý od Krakowa po Tczew. Über das Wisla-Phytoseston zwischen Kraków und Tczew. Acta Hydrobiol. (Kraków) 12, 161-190.

Utermöhl, H. 1958. Zur Vervollkommnung der quantitativen Phytoplankton-Methodik. Mitteilunger der internationale Vereinigunk für theoretische und angewandte Limnologie, 9, 1-38.

van Dam, H., Stenger-Kovács, C., Ács, É., Borics, G., Buczkó, K., Hajnal, É., et al., 2007. Implementation of the European Water Framework Directive: Development of a system for water quality assessment of Hungarian running waters with diatoms. Archiv für Hydrobiologie Suppl. 161, 339-383.

Vannote, R.L., Minshall, W.G., Cummins, K.W., Sedell, J.R., Cushing, C.E., 1980. The river continuum concept. Candian Journal of Fisheries and Aquatic Sciences 37, 130-137. 
545 Várbíró, G., Ács, É., Borics, G., Érces, K., Fehér, G., Grigorszky, I., et al., 2007. Use of self546 organising maps SOM for characterization of riverine phytoplankton associations in Hungary. $547 \quad$ Archiv für Hydrobiologie 161, 383-394.

548 Várbíró, G., Borics, G., Csányi, B., Fehér, G., Grigorszky, I., Kiss, K.T., et al., 2012. Improvement of 549 the ecological water qualification system of rivers based on the first results of the Hungarian 550 phytobenthos surveillance monitoring. Hydrobiologia 695, 125-135.

551 Vörös, L., V.-Balogh, K., Herodek, S., Kiss, K.T., 2000. Underwater light conditions, phytoplankton 552 photosynthesis and bacterioplankton production in the Hungarian section of the River Danube. 553 Arch. Hydrobiol., Large Rivers. 11, 511-532.

554 Ward, J.V., Stanford, J.A., 1983. The serial discontinuity concept of lotic ecosystems. Dynamics of $555 \quad$ lotic ecosystems $10,29-42$.

556 Wehr, J.D., Descy, J.-P., 1998. Use of phytoplankton in large river management. Journal of Phycology $557 \quad 34,741-749$.

558 Welker, M., Walz, N., 1999. Plankton dynamics in a river-lake system-on continuity and 559 discontinuity. In: Shallow Lakes' 98. Springer Netherlands 233-239. 


\section{Legends for figures and tables}

564 Table 1. Chemical, physical, and morphological features of the rivers.

566 Table 2. Observed numbers of taxa in the sampled habitats.

Table 3. Pearson correlation values and $p$ values of the correlations between the diatom indices calculated for plankton samples and for the substrates (significant correlations are indicated with bold).

Fig. 1. a: Relative abundance (percentage \%) of the benthic diatoms (black) and other groups of algae (grey) in the rhithroplankton of streams in different river orders; b: Percentage of the number of taxa (black: benthic diatoms, grey: others) in the rhithroplankton of streams in different river orders.

Fig. 2 a: Relative abundance (percentage \%) of the non-diatom algae belonging to the various functional groups in the rhithroplankton of streams in different river orders; b: Percentage of the number of taxa belonging to the various functional groups in the rhithroplankton of streams in different river orders.

Fig. 3. Sample-based rarefaction (solid lines) and extrapolation (dotted lines) curves of the diatom species diversity for the plankton and for benthic substrates. The 95\% confidence intervals (grey shades) are obtained by a bootstrap method based on 200 replications. The symbols represent the observed number of species.

Fig. 4 a Euclidean distances of diatom assemblages of the various substrates from the rhithroplankton; b: Jaccard similarities of diatom assemblages of the various substrates to the rhithroplankton.

Fig. 5 a: Percentage of centric diatoms in the rhithroplankton samples (stream sizes are expressed as distances from the sources and indicated on the x axis; symbols: •- sample sites on the River Hernád; ж- sample sites on the River Sajó; b: Percentage of planktonic species in benthic samples (stream sizes are expressed as distances from the sources and indicated on the $\mathrm{x}$ axis; symbols: •- sample sites on the River Hernád; $*$ - sample sites on the River Sajó.

Fig. 6 a. Distribution of IPS diatom index values in the five benthic substrates and in the rhithroplankton samples; b: Distribution of SID diatom index values in the five benthic substrates and in the rhithroplankton samples; c: Distribution of TID diatom index values in the five benthic substrates and in the rhithroplankton samples. 
599 Fig. 7 a: Differences between the IPS values calculated for the substrate "stone thalweg" and the 600 rhithroplankton samples (Difference stone, plankton $=\mathrm{IPS}_{\text {stone }}-\mathrm{IPS}_{\text {plankton }}$; stream sizes are expressed as 601 distances from the sources and indicated on the $\mathrm{x}$ axis); b: Differences between the IPS values 602 calculated for the substrate "plant" and the rhithroplankton (Difference plant, plankton $=\mathrm{IPS}_{\text {plant }}-\mathrm{IPS}_{\text {plankton}}$; 603 stream sizes are expressed as distances from the sources and indicated on the $\mathrm{x}$ axis). Grey areas 604 represent different river sections. 
Chemical, physical, and morphological features of rivers

Stream order

Elevation of source ( $m$ asl.)

Catchment area $\left(\mathrm{km}^{2}\right)$

Length $(\mathrm{km})$

Minimum and maximum discharge $\left(\mathrm{m}^{3} \mathrm{~s}^{-1}\right)$

Average discharge (min. and max.) $\left(\mathrm{m}^{3} \mathrm{~s}^{-1}\right)$

Minimum and maximum water residence time (day)

Mean precipitation in the watershed $(\mathrm{mm})$

Mean temperature $\left({ }^{\circ} \mathrm{C}\right)$

$\mathrm{pH}$

Conductivity ( $\left.\mu \mathrm{S} \mathrm{cm}{ }^{-1}\right)$

Dissolved $\mathrm{O}_{2}(\mathrm{mg} / \mathrm{l})$

Water temperature $\left({ }^{\circ} \mathrm{C}\right)$

\begin{tabular}{c|c} 
Sajó & Hernád \\
& \\
$1^{\text {st }}$ to $6^{\text {th }}$ & $1^{\text {st }}$ to $5^{\text {th }}$ \\
1280 & 1500 \\
12708 & 5436 \\
223 & 286 \\
$2-545$ & $6-450$ \\
60 & 28 \\
$7.5-13.2$ & $7.6-11.3$ \\
$600-1250$ \\
23 & 21 \\
8.2 & 8.24 \\
562.62 & 387.04 \\
8.13 & 8.19 \\
23 & 20.9
\end{tabular}


615 Table 2.

\begin{tabular}{lll}
\hline Habitat type & $\begin{array}{l}\text { Observed } \\
\text { number of taxa }\end{array}$ & $\begin{array}{l}\text { Number of } \\
\text { samples }\end{array}$
\end{tabular}

\begin{tabular}{lll}
\hline Rhithroplankton & 253 & 42 \\
Stone thalweg & 208 & 33 \\
Plant & 202 & 35 \\
Wood & 196 & 35 \\
Stone pool & 148 & 17 \\
Psammon & 137 & 8 \\
\hline
\end{tabular}

616

617

618 
621 Table 3.

\begin{tabular}{rrrr}
\hline & IPS & SID & TID \\
\hline \multirow{2}{*}{ wood } & $\mathbf{0 . 4 4 4 1}$ & $\mathbf{0 . 5 2 6 9}$ & $\mathbf{0 . 7 0 2 0}$ \\
& $\mathrm{N}=\mathbf{3 5}$ & $\mathrm{N}=\mathbf{3 5}$ & $\mathrm{N}=\mathbf{3 5}$ \\
& $\mathrm{p}=\mathbf{0 . 0 0 9}$ & $\mathrm{p}=\mathbf{0 . 0 0 1}$ & $\mathrm{p}=\mathbf{0 . 0 0 0}$
\end{tabular}

stone, pool

$\begin{array}{lll}0.2911 & 0.0467 & \mathbf{0 . 4 5 5 1}\end{array}$

$\mathrm{N}=17 \quad \mathrm{~N}=17 \quad \mathrm{~N}=17$

$p=0.141 \quad p=0.817 \quad p=0.017$

stone, thalweg

$\begin{array}{lll}0.5923 & 0.4265 & 0.5916\end{array}$

$\mathrm{N}=33 \quad \mathrm{~N}=33 \quad \mathrm{~N}=33$

$p=0.001 p=0.019 p=0.001$

plant

$\begin{array}{lll}0.6998 & 0.6047 & 0.7549\end{array}$

$\mathrm{N}=35 \quad \mathrm{~N}=35 \quad \mathrm{~N}=35$

$p=0.000 p=0.000 p=0.000$

psammon

\begin{tabular}{rrr}
0.5391 & 0.4432 & $\mathbf{0 . 7 3 1 5}$ \\
$N=8$ & $N=8$ & $\mathbf{N}=8$ \\
$p=0.168$ & $p=0.271$ & $p=0.039$ \\
\hline
\end{tabular}


625 Fig. 1
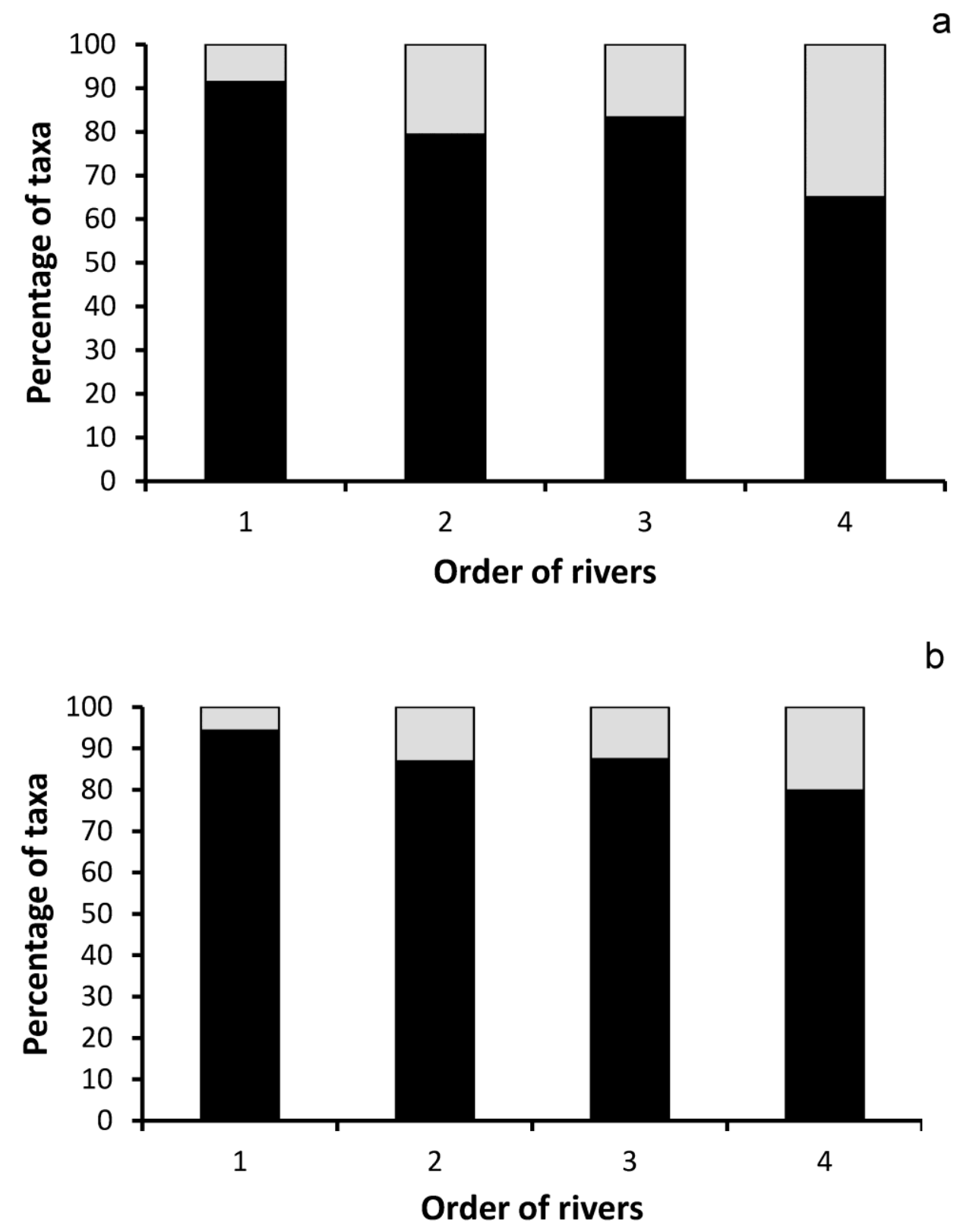


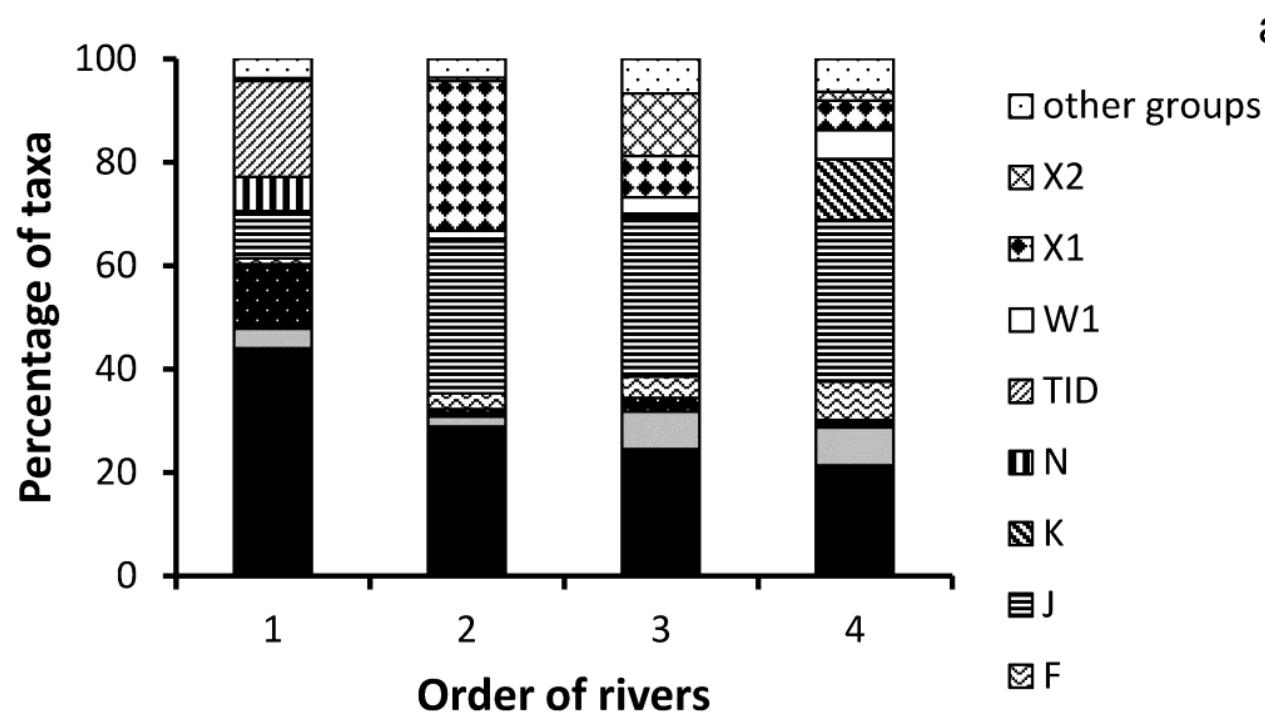

a

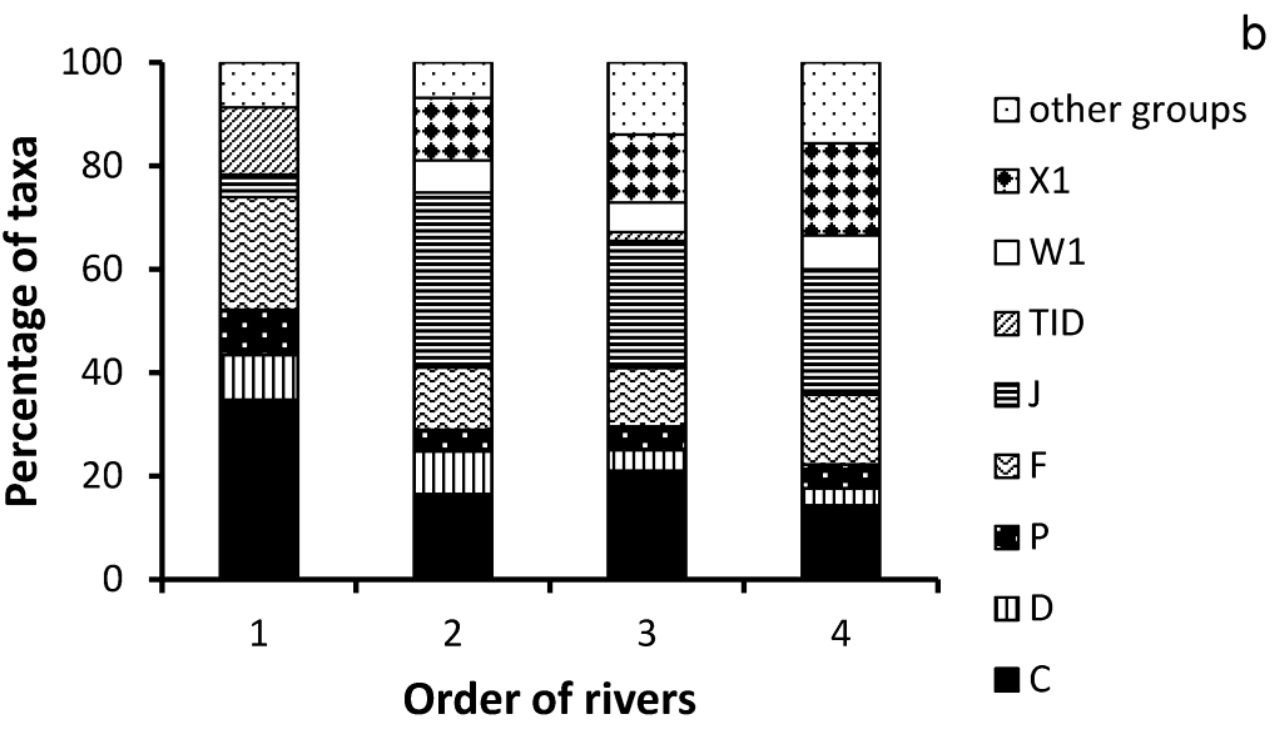


Fig. 3

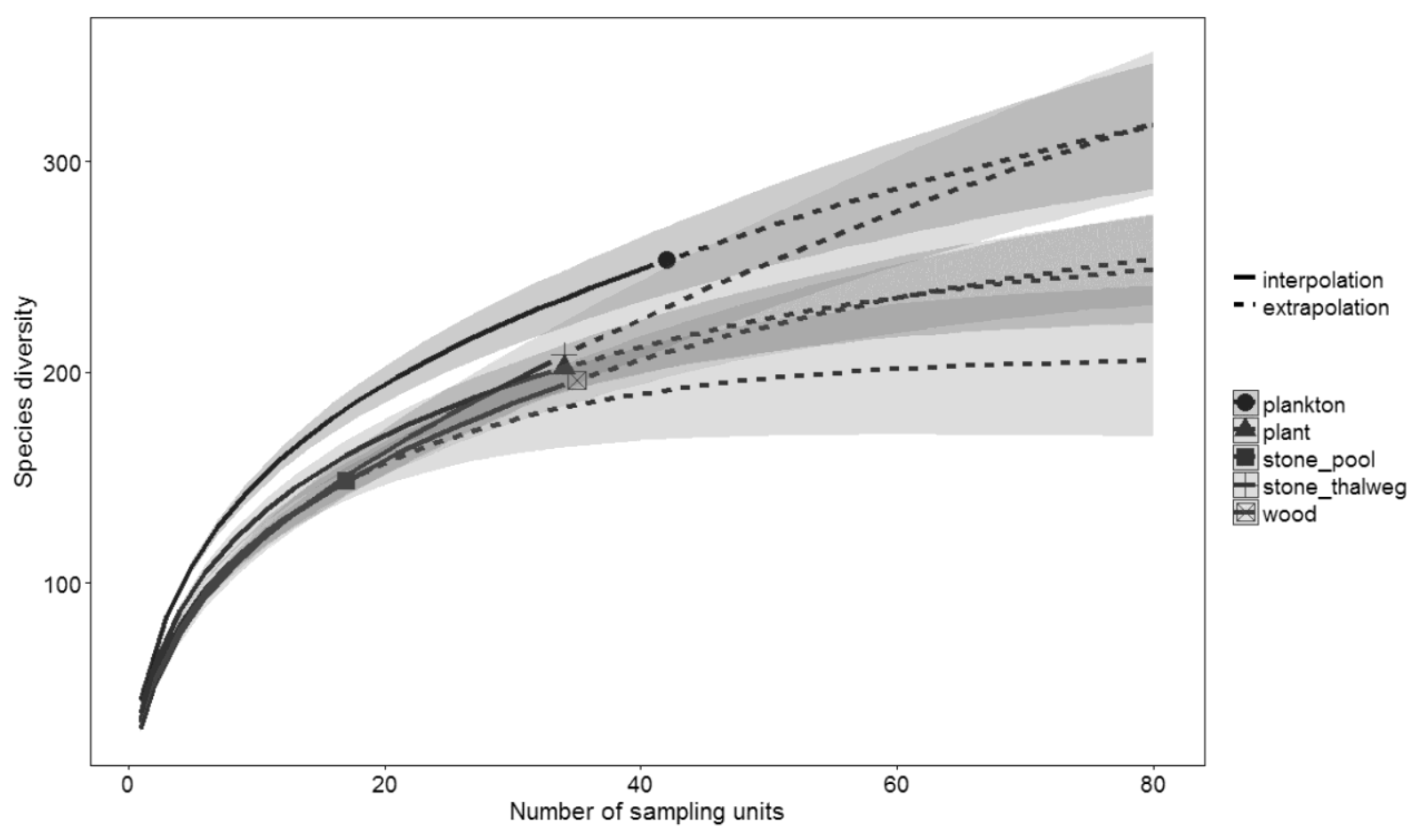

632 
Fig. 4
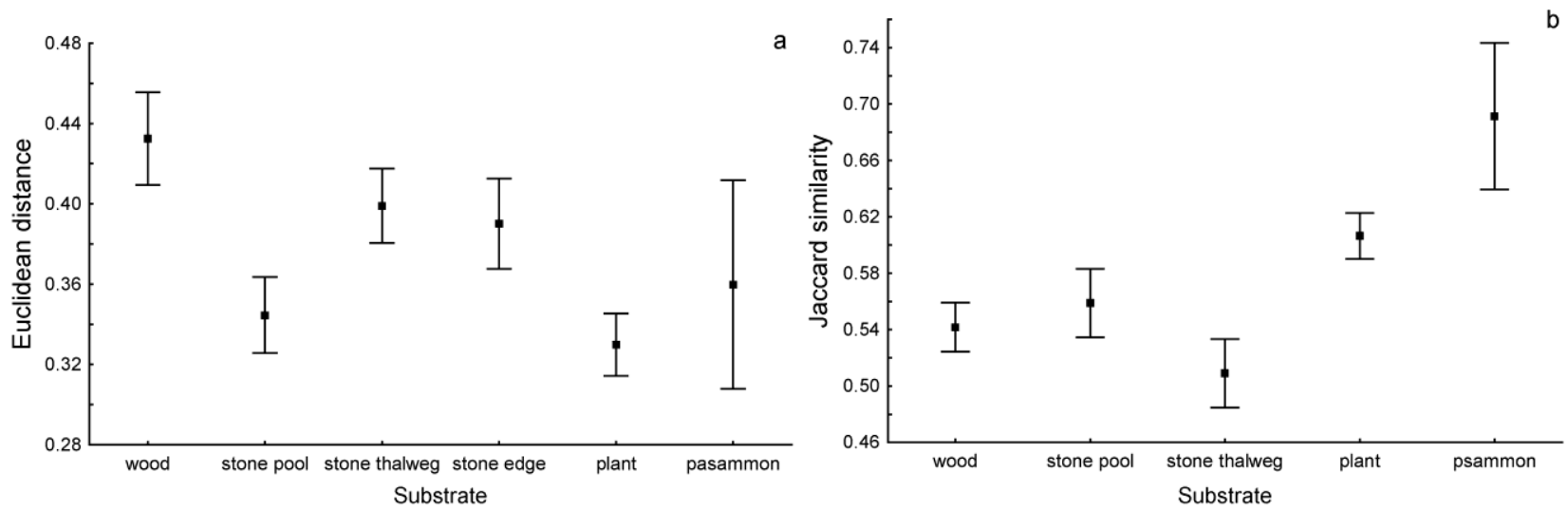

637 Fig. 5
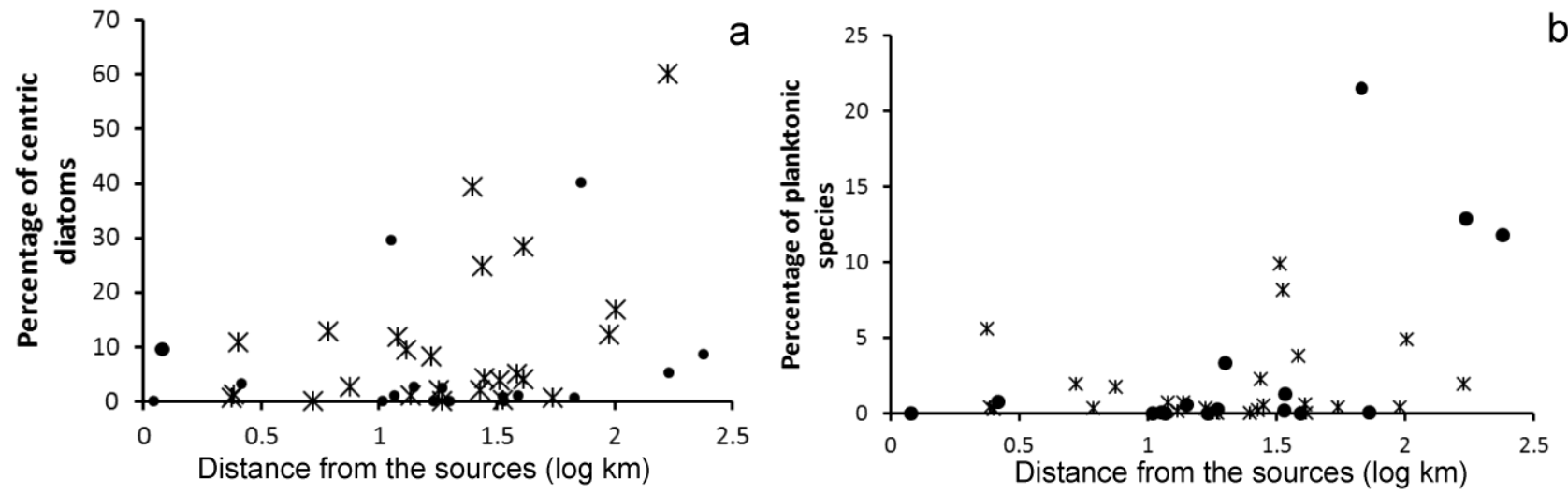
642 Fig. 6
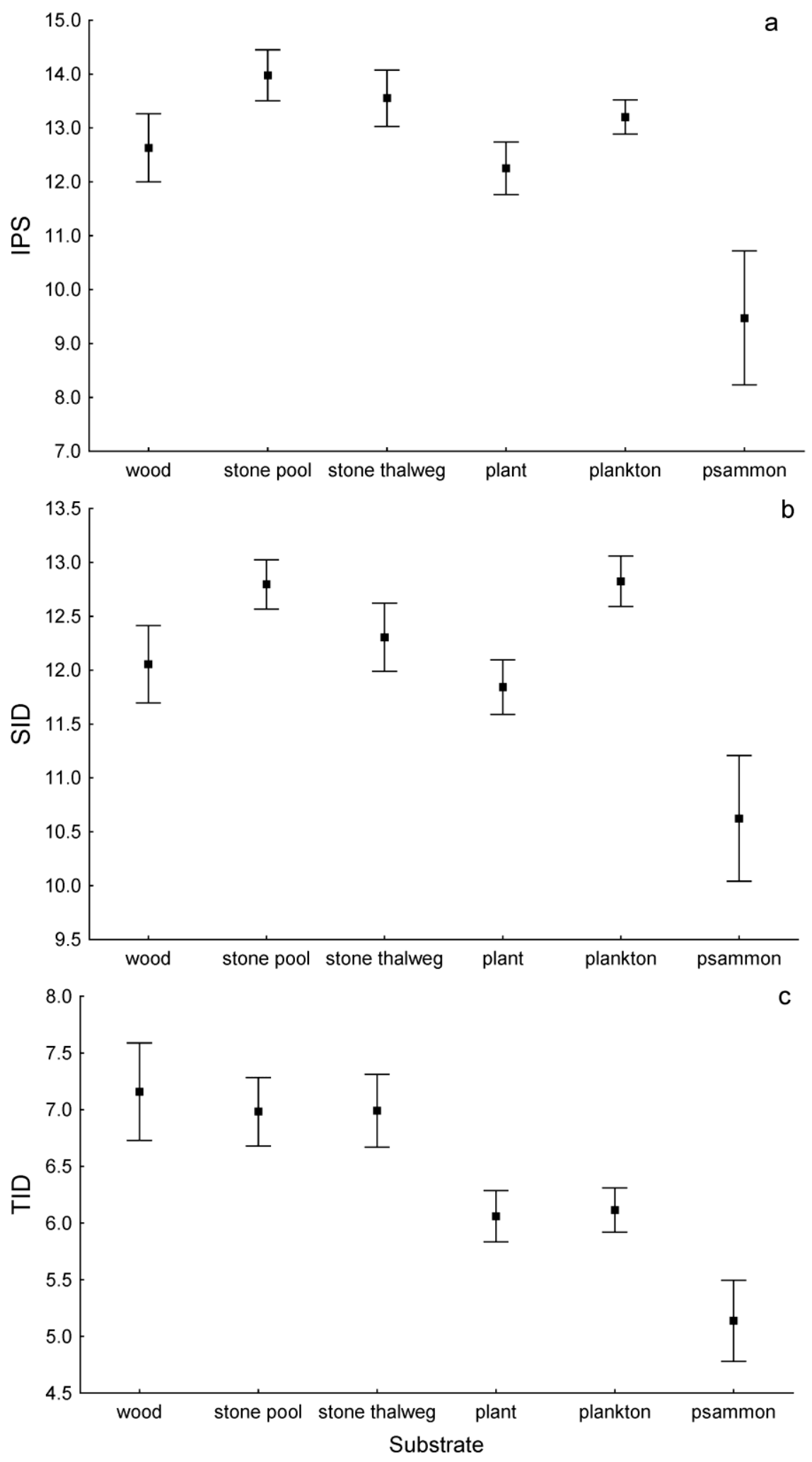

643 


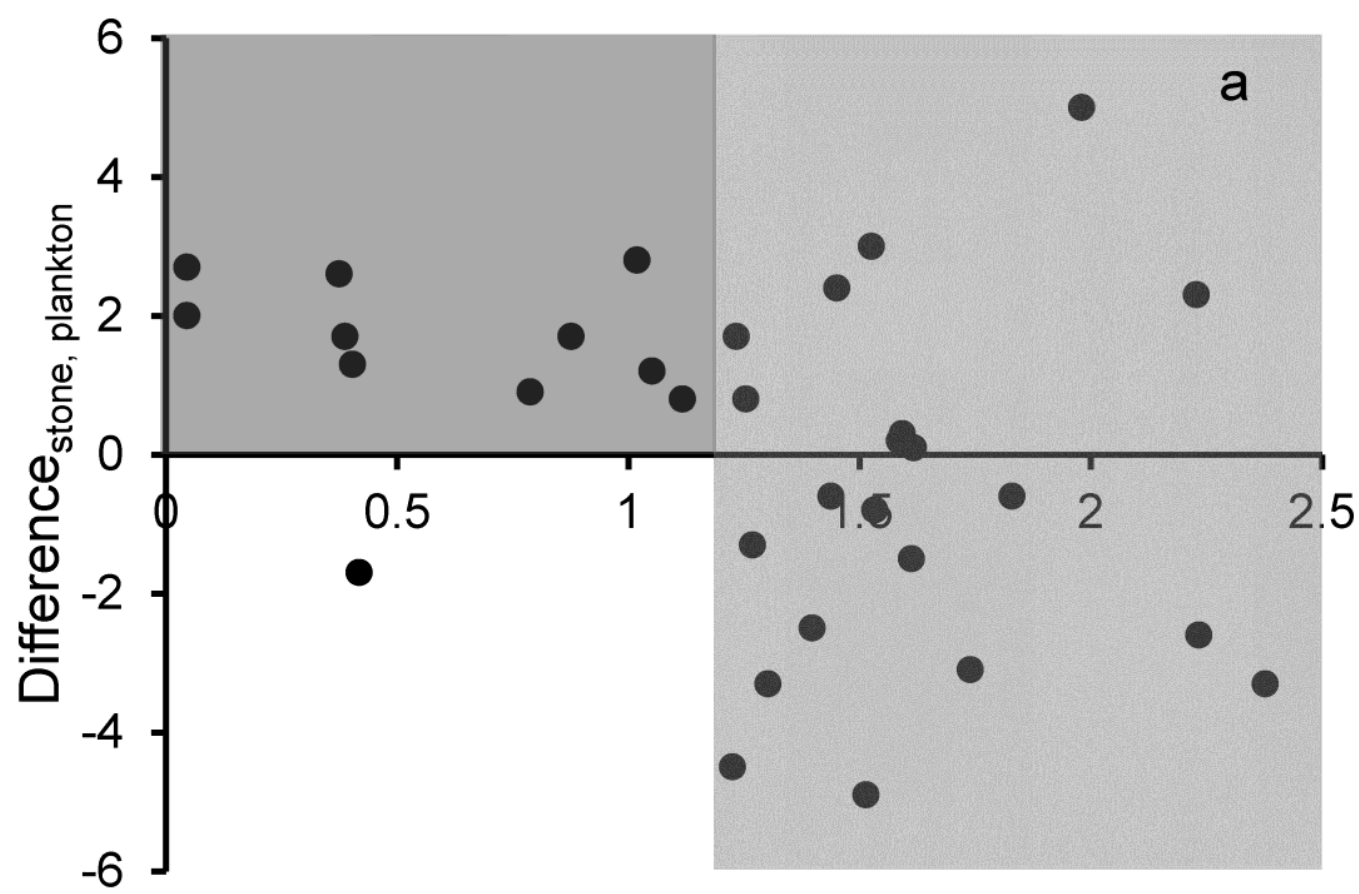

Distance from the sources (log km)

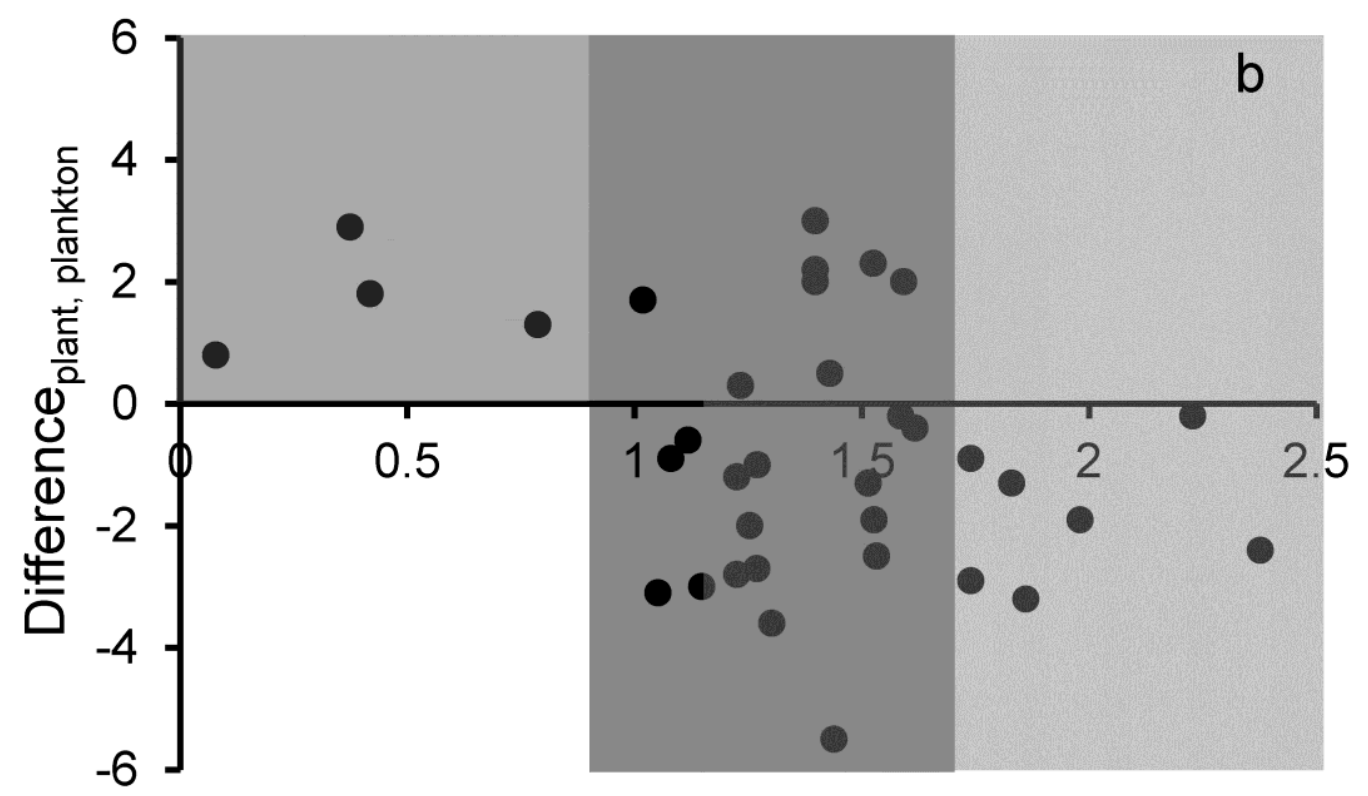

Distance from the sources (log $\mathrm{km})$ 